\title{
Two Iranian Rice Cultivars' Response to Nitrogen and Nano-Fertilizer
}

\author{
Mehrdad Ghasemi Lemraski ${ }^{1}$, Ghorban Normohamadi' ${ }^{1}$ Hamid Madani2 ${ }^{2}$ \\ Hussein Heidari Sharif Abad', Hamid Reza Mobasser ${ }^{3}$ \\ ${ }^{1}$ Department of Agronomy, Science and Research Branch, Islamic Azad University, Tehran, Iran \\ ${ }^{2}$ Department of Agronomy, Arak Branch, Islamic Azad University, Arak, Iran \\ ${ }^{3}$ Department of Agronomy, Qaemshahr Branch, Islamic Azad University, Qaemshahr, Iran \\ Email: gnoorm@yahoo.com
}

How to cite this paper: Lemraski, M.G., Normohamadi, G., Madani, H., Abad, H.H.S. and Mobasser, H.R. (2017) Two Iranian Rice Cultivars' Response to Nitrogen and $\mathrm{Na}$ no-Fertilizer. Open Journal of Ecology, 7, 591-603.

https://doi.org/10.4236/oje.2017.710040

Received: May 22, 2017

Accepted: September 15, 2017

Published: September 18, 2017

Copyright (c) 2017 by authors and Scientific Research Publishing Inc. This work is licensed under the Creative Commons Attribution International License (CC BY 4.0).

http://creativecommons.org/licenses/by/4.0/ cC) (†) Open Access

\begin{abstract}
This experiment was carried out as split factorial in randomized complete blocks design with three replications in Sari, Iran during 2013 and 2014. Rice cultivars were chosen as the main factor including Tarom Mahalli and Tarom Hashemi. Nitrogen rates (34 and $69 \mathrm{~kg} \mathrm{~N} \mathrm{ha}^{-1}$ and nitroxin) with nano-particle (nano-potassium, nano-silicon and control) selected as the subfactor. The results indicated that the amount of total tiller per hill and fertile tiller per hill for Tarom Hashemi was more than Tarom Mahalli in both years. The highest paddy yield in both years was observed for Tarom Hashemi, the main reason behind it is increasing panicle length and fertile tiller number for this cultivar. For Tarom Hashemi, the highest paddy yield $\left(5000 \mathrm{~kg} \cdot \mathrm{ha}^{-1}\right)$ was produced with $34 \mathrm{~kg} \mathrm{~N} \mathrm{ha}^{-1}$ and nano potassium application. For Tarom Mahalli, the highest paddy yield $4657 \mathrm{~kg} \cdot \mathrm{ha}^{-1}$ was obtained with nitroxin and nano potassium consumption. The highest harvest index was achieved with nitroxin and nano-silicon consumption. Therefore, nano particle consumption in both cultivars resulted in improved yield.
\end{abstract}

\section{Keywords}

Nano Particle, Nitrogen, Nano Silicon, Rice, Yield

\section{Introduction}

Rice (Oryzasativa L.) is the main staple food for more than half of the population worldwide. In 2011, worldwide rice production exceeded 672 million mt. Iran has been ranked 20th in terms of rice production internationally speaking [1]. Fertilizers have an important role in enhancing food production and quality es- 
pecially after the introduction of high-yielding and fertilizer responsive varieties. Most of the major crops grown such as rice require large quantities of inorganic inputs. Studies have been conducted to improve rice production but only a few can be seen in the literature involving nano-materials [2]-[8]. Nano-materials are defined as the materials with a single unit between 1 and $100 \mathrm{~nm}$ in size in at least one dimension [9]. Some studies already proved the significance of nano-fertilizers. Some beneficial effects include increased nutrient use efficiency, better yield and reduced soil pollution [10]. Rice yield largely depends on soil conditions and also on the supply of the available nutrients like nitrogen, phosphorus, potassium, sulphur and zinc [11]. Rice plants require large amounts of mineral nutrients including nitrogen for their growth, development, and grain production [12]. The development of efficient nitrogen management protocols requires recognizing cultivar differences and critical stages of crop growth that fertilization is necessary to avoid potential yield loss [13]. Managing rice crop's nitrogen nutrition is difficult because lowland rice crop culture leads to nitrogen losses through ammonia volatilization, nitrification, denitrification, leaching, and runoff [14], which decreases the availability of nitrogen for rice plants. Grain protein concentration is directly related to nitrogen concentration in grains [15]. Rice is the most widely consumed cereal in the world [16]. Therefore, it is important for rice breeders to consider selecting highly efficient genotypes in remobilizing nitrogen from vegetative parts to the grain or genotypes with high grain protein concentration. Grain yield rise can be attributed to the increasing number of grains per panicle [17]. Spikelet fertility has also been associated with rice silicon concentration [18]. Rice low productivity observed in dry land systems results from a series of biotic and abiotic factors. Among these factors, we can mention the occurrence of diseases, inadequate rainfall distribution in the main producing regions, and little fertilizers and lime use [19]. Within the nutrients group, silicon is not considered as essential or functional for plant growth; however, its absorption brings several benefits especially for rice, such as increased cell wall thickness below the cuticle [20], imparting mechanical resistance to the fungi penetration, transpiration drop [20], and leaf angle improvement, making leaves more erect, thus reducing self-shading, especially under high nitrogen rates [21]. A positive correlation has been observed between grain yield and 1000 -seed weight at $5 \%$ probability level. Harvest index and rice straw had positive correlation at $1 \%$ probability level. Hence, the treatment of irrigation halting and silicon amount has shown maximum effect in 1000-seed weight compared to other contributing parameters to yield [22]. Yield rise via adding silicon was attributed to a great number of grains per panicle, whereas 1000-seed weight and the number of panicle per square meter exhibited less change [17]. Therefore, silicon alone could boost grain rice cultivars' yields without further genetic improvements. Silicon helps plants to overcome multiple stresses including the biotic and abiotic ones [12]. For instance, silicon plays an important role in increasing plants' resistance to pathogens such as blast on rice 
[23]. Silicon also alleviates other abiotic stresses' effects including salt stress, metal toxicity, drought stress, radiation damage, nutrient imbalance, high temperature, and freezing [12] [24]. Increased levels of silicon in rice plants are associated with dropped grain discoloration levels at harvest. Silicon has been reported to reduce rice seeds shattering and to increase filled grains number and weight [25]. Therefore, this research aims to evaluate nitrogen nano-fertilizers' effect on rice cultivars growth.

\section{Material and Methods}

The field experiment was conducted in Sari, the northern part of Iran (Latitude $36^{\circ} 38 \mathrm{~N}$, Longitude $53^{\circ} 12 \mathrm{E}$ and Altitude $13.5 \mathrm{~m}$ above sea level), in 2013 and 2014. Meteorology, physical and chemical properties of soil characteristics location of this experiment were presented in Table 1 and Table 2, respectively.

Table 1. Selected soil traits for composite samples at experimental site.

\begin{tabular}{cccc}
\hline Soil traits & Unit & 2013 & 2014 \\
\hline Soil depth & $\mathrm{cm}$ & $0-30$ & $0-30$ \\
$\mathrm{EC}$ & $\mathrm{dS} \cdot \mathrm{m}^{-1}$ & 0.68 & 0.62 \\
$\mathrm{pH}$ & - & 7.8 & 7.6 \\
Organic matter & $\%$ & 1.5 & 1.4 \\
$\mathrm{~N}$ & $\%$ & 0.12 & 0.10 \\
$\mathrm{P}$ & $\mathrm{ppm}$ & 8 & 9 \\
$\mathrm{~K}$ & $\mathrm{ppm}$ & 140 & 165 \\
$\mathrm{Mg}$ & $\mathrm{mg} / \mathrm{kg}$ & 704 & 680 \\
$\mathrm{Fe}$ & $\mathrm{mg} / \mathrm{kg}$ & 33.7 & 29 \\
$\mathrm{Mn}$ & $\mathrm{mg} / \mathrm{kg}$ & 8.3 & 7.6 \\
$\mathrm{Zn}$ & $\mathrm{mg} / \mathrm{kg}$ & 1.2 & 1.4 \\
$\mathrm{Cu}$ & $\mathrm{mg} / \mathrm{kg}$ & 3.9 & 3.5 \\
Soil texture & - & Clay & Loam clay \\
\hline
\end{tabular}

Table 2. Weather condition in experiment site in rice growth stages.

\begin{tabular}{ccccc}
\hline Months & $\begin{array}{c}\text { Rainfall level } \\
(\mathrm{Mm})\end{array}$ & $\begin{array}{c}\text { Monthly } \\
\text { evaporation }(\mathrm{Mm})\end{array}$ & $\begin{array}{c}\text { Maximum } \\
\text { Temperature }\left({ }^{\circ} \mathrm{C}\right)\end{array}$ & $\begin{array}{c}\text { Minimum } \\
\text { Temperature }\left({ }^{\circ} \mathrm{C}\right)\end{array}$ \\
\hline \multirow{2}{*}{ 20 Mar - 20 Apr } & 12.4 & 110.3 & 20.5 & 9.2 \\
& 12 & 91.5 & 19.3 & 9.8 \\
20 Apr - 20 May & 10.6 & 187.5 & 27.0 & 15.8 \\
& 42.6 & 134.9 & 24.6 & 13.2 \\
20 May - 20 June & 41.4 & 222.5 & 20.6 & 19.8 \\
& 9.3 & 166.4 & 29.1 & 18.7 \\
20 June - 20 July & 16.8 & 144.1 & 30.0 & 22.2 \\
& 0 & 217.3 & 31.7 & 21.2 \\
20 July - 20 Aug & 2.6 & 204.6 & 34.1 & 23.1 \\
& 29.5 & 133.4 & 30.3 & 21.4 \\
20 Aug - 20 Sep & 100.3 & 135.7 & 29.9 & 21.1 \\
& 10.8 & 122.2 & 31.1 & 21.4 \\
\hline
\end{tabular}


Rice cultivars were chosen as the main factor including Tarom Mahalli and Tarom Hashemi. Nitrogen rates (34 and $69 \mathrm{~kg} \mathrm{~N} \mathrm{ha}^{-1}$ and nitroxin) with nanoparticle (nano-potassium, nano-silicon and control) selected as the sub-factor. Clean seeds with a minimum of $95 \%$ germination rate were soaked in water for $24 \mathrm{~h}$ and incubated for another $24 \mathrm{~h}$. Then, the pre-germinated seeds were sown in seedling trays filled with soil to produce uniform seedlings. The total number of unit was 54 plots. Each plot was in $2 \times 5 \mathrm{~m}^{2}$ size. After transplanting, five centimetres water depth was maintained in the experimental plots. Ten days before harvest, the plots were drained to facilitate harvest. Insects, diseases, and weeds were intensively controlled to avoid any yield loss. Phosphorous fertilizers were used at the rates of $100 \mathrm{~kg} \mathrm{P}_{2} \mathrm{O}_{5} \mathrm{ha}^{-1}$ as urea and triple superphosphate as basal fertilizers, respectively. Basal fertilizers were applied and incorporated in all plots one day before transplanting. Nitrogen was split-applied in the form: $50 \mathrm{~kg} \mathrm{~N}$ $\mathrm{ha}^{-1}$ at basal, $50 \mathrm{~kg} \mathrm{~N} \mathrm{ha}^{-1}$ at panicle initiation, $50 \mathrm{~kg} \mathrm{~N} \mathrm{ha}^{-1}$ at full heading. The traits of panicle length (on average, 20 clusters per plot), plant height, the number of total tillers and the number of the effective tillers per hill (on average, 12 piles per plot), paddy yield (with the harvest of $4 \mathrm{~m}^{2}$ from the middle of each plot $)$ and harvest index [(Grain yield/Biological yield $) \times 100]$ were measured. The obtained data were analysed with statistical software SAS and the averages were compared through LSD multiple range test at probability level 0.05. Also the charts and tables were drawn with Excel.

\section{Results and Discussion}

\subsection{Plant Height and Panicle Length}

Plant height and panicle length had significant effect under cultivar treatment at probability level $1 \%$ in both years. In the 1 st year, plant height had meaningful effect under nitrogen treatment at probability level 5\%. Also in the 2nd year, panicle length was significant under the nano particles' effect and double interaction of nitrogen and nano particle at probability level 5\% (Table 3). In both years, the plant height for Tarom Hashemi $(136.26$ and $143.14 \mathrm{~cm})$ was more than that of Tarom Mahalli cultivar $(127.45$ and $130.08 \mathrm{~cm})$. Also, in both years, the panicle length for Tarom Hashemi $(27.72$ and $28.97 \mathrm{~cm})$ was more than that of Tarom Mahalli cultivar $(24.81$ and $23.68 \mathrm{~cm})$. The maximum plant height $133.87 \mathrm{~cm}$ was observed with $34 \mathrm{~kg} \mathrm{~N} \mathrm{ha}^{-1}$ and the minimum plant height 129.62 $\mathrm{cm}$ was achieved with nitroxin. Also the maximum panicle length $26.88 \mathrm{~cm}$ was observed with using nano-silicon (Table 4). The maximum panicle length under double interaction of nitrogen and nano particle was gained with 34 and $69 \mathrm{~kg} \mathrm{~N}$ $\mathrm{ha}^{-1}$ with applying nano silicon (corresponding 27.02 and $27.15 \mathrm{~cm}$ ) and nitroxin use with control treatment $(27.13 \mathrm{~cm})$. Also the lowest panicle length was seen in other interactions (Figure 1). Nitrogen influenced jiberlin hormone indirectly through cytoxin. Thus, it resulted in the growth increase of the branches' end parts and the plant young leaves and about rice, it raised the number of the tillers [26]. In a research by Bahmaniar and Sooaee Mashaee (2010), 
Table 3. Variance analysis of Morphological characteristics and yield component under the effects of density and time of nitrogen application.

\begin{tabular}{|c|c|c|c|c|c|c|c|c|c|c|c|c|c|}
\hline \multirow{2}{*}{ S.O.V } & \multirow{2}{*}{$\mathrm{df}$} & \multicolumn{2}{|c|}{$\begin{array}{l}\text { Plant } \\
\text { height }\end{array}$} & \multicolumn{2}{|c|}{$\begin{array}{l}\text { Panicle } \\
\text { length }\end{array}$} & \multicolumn{2}{|c|}{$\begin{array}{c}\text { No. Tiller } \\
\text { per hill }\end{array}$} & \multicolumn{2}{|c|}{$\begin{array}{l}\text { No. Fertile } \\
\text { tiller per hill }\end{array}$} & \multicolumn{2}{|c|}{$\begin{array}{l}\text { Paddy } \\
\text { yield }\end{array}$} & \multicolumn{2}{|c|}{$\begin{array}{l}\text { Harvest } \\
\text { index }\end{array}$} \\
\hline & & 2013 & 2014 & 2013 & 2014 & 2013 & 2014 & 2013 & 2014 & 2013 & 2014 & 2013 & 2014 \\
\hline Repeat (R) & 2 & $72.62^{*}$ & $349.25^{\star *}$ & $4.44^{*}$ & 2.48 & $32.78^{\star *}$ & $22.77^{\star *}$ & 4.02 & $22.24^{* *}$ & $683251.85^{*}$ & $126705.56 \mathrm{~ns}$ & $2.12 \mathrm{~ns}$ & $1.09 \mathrm{~ns}$ \\
\hline Cultivar (C) & 1 & $104.91^{\star *}$ & $2302.08^{\star \star}$ & $206.98^{\star *}$ & $377.47^{\star *}$ & $13.67^{\star}$ & $15.09^{*}$ & $15.52^{*}$ & $6.00^{*}$ & $1622400.00^{* *}$ & $1284979.63^{\star \star}$ & $8.49 \mathrm{~ns}$ & $1.56 \mathrm{~ns}$ \\
\hline $\mathrm{R} \times \mathrm{C}$ & 2 & 45.94 & 38.18 & 0.26 & 3.07 & 2.69 & 1.46 & 5.69 & 0.39 & 334822.22 & 147404.07 & 40.80 & 23.66 \\
\hline Nitrogen $(\mathrm{N})$ & 2 & $82.13^{*}$ & $98.25 \mathrm{~ns}$ & $0.92 \mathrm{~ns}$ & $0.84 \mathrm{~ns}$ & $80.26^{* *}$ & $14.79^{*}$ & $48.30^{* *}$ & $15.41^{\star *}$ & $4924.07 \mathrm{~ns}$ & $42016.67 \mathrm{~ns}$ & $41.16^{* *}$ & $14.94^{*}$ \\
\hline $\mathrm{C} \times \mathrm{N}$ & 2 & $3.69 \mathrm{~ns}$ & $17.15 \mathrm{~ns}$ & $1.09 \mathrm{~ns}$ & $0.90 \mathrm{~ns}$ & $1.41 \mathrm{~ns}$ & $0.86 \mathrm{~ns}$ & $3.63 \mathrm{~ns}$ & $0.22 \mathrm{~ns}$ & $115772.22 \mathrm{~ns}$ & $110812.96 \mathrm{~ns}$ & $1.68 \mathrm{~ns}$ & $1.99 \mathrm{~ns}$ \\
\hline Nano particles $(\mathrm{P})$ & 2 & $13.01 \mathrm{~ns}$ & $15.80 \mathrm{~ns}$ & $1.51 \mathrm{~ns}$ & $4.19^{*}$ & $1.30 \mathrm{~ns}$ & $2.53 \mathrm{~ns}$ & $0.57 \mathrm{~ns}$ & $0.96 \mathrm{~ns}$ & $382812.96 \mathrm{~ns}$ & $254772.22 \mathrm{~ns}$ & $5.14 \mathrm{~ns}$ & $6.84 \mathrm{~ns}$ \\
\hline $\mathrm{C} \times \mathrm{P}$ & 2 & $35.64 \mathrm{~ns}$ & $12.27 \mathrm{~ns}$ & $1.41 \mathrm{~ns}$ & $1.88 \mathrm{~ns}$ & $1.48 \mathrm{~ns}$ & $5.31 \mathrm{~ns}$ & $2.35 \mathrm{~ns}$ & $2.89 \mathrm{~ns}$ & $106672.22 \mathrm{~ns}$ & $10279.63 \mathrm{~ns}$ & $6.24 \mathrm{~ns}$ & $2.93 \mathrm{~ns}$ \\
\hline $\mathrm{N} \times \mathrm{P}$ & 4 & $46.34 \mathrm{~ns}$ & $44.52 \mathrm{~ns}$ & $3.22 \mathrm{~ns}$ & $3.67^{*}$ & $1.72 \mathrm{~ns}$ & $2.72 \mathrm{~ns}$ & $0.69 \mathrm{~ns}$ & $0.91 \mathrm{~ns}$ & $343776.85 \mathrm{~ns}$ & 184197.22 ns & $9.88^{*}$ & $4.44 \mathrm{~ns}$ \\
\hline $\mathrm{C} \times \mathrm{N} \times \mathrm{P}$ & 4 & $23.72 \mathrm{~ns}$ & $19.72 \mathrm{~ns}$ & $1.19 \mathrm{~ns}$ & $0.92 \mathrm{~ns}$ & $2.91 \mathrm{~ns}$ & $3.76 \mathrm{~ns}$ & $2.30 \mathrm{~ns}$ & $1.94 \mathrm{~ns}$ & $334402.78 \mathrm{~ns}$ & $476671.30^{\star}$ & $5.10 \mathrm{~ns}$ & $1.87 \mathrm{~ns}$ \\
\hline Error & 32 & 22.52 & 43.17 & 1.64 & 1.60 & 2.64 & 3.34 & 2.14 & 2.06 & 180403.70 & 159806.48 & 4.28 & 5.36 \\
\hline CV (\%) & - & 3.60 & 4.81 & 4.78 & 4.84 & 8.70 & 13.04 & 11.42 & 14.48 & 9.37 & 9.32 & 4.68 & 5.38 \\
\hline
\end{tabular}

*, **, NS: significant at $5 \%$ and $1 \%$ probability levels and non-significant, respectively.

Table 4. Mean comparison of nitrogen and nano fertilizers in some parameters of rice cultivars.

\begin{tabular}{|c|c|c|c|c|c|c|c|c|c|c|c|c|}
\hline \multirow{2}{*}{ Treatment } & \multicolumn{2}{|c|}{$\begin{array}{l}\text { Plant height } \\
\qquad(\mathrm{cm})\end{array}$} & \multicolumn{2}{|c|}{$\begin{array}{l}\text { Panicle length } \\
(\mathrm{cm})\end{array}$} & \multicolumn{2}{|c|}{$\begin{array}{l}\text { No. Tiller } \\
\text { per hill }\end{array}$} & \multicolumn{2}{|c|}{$\begin{array}{l}\text { No. Fertile } \\
\text { tiller per hill }\end{array}$} & \multicolumn{2}{|c|}{$\begin{array}{l}\text { Paddy yield } \\
\left(\mathrm{kg} \cdot \mathrm{ha}^{-1}\right)\end{array}$} & \multicolumn{2}{|c|}{$\begin{array}{l}\text { Harvest index } \\
\text { (\%) }\end{array}$} \\
\hline & 2013 & 2014 & 2013 & 2014 & 2013 & 2014 & 2013 & 2014 & 2013 & 2014 & 2013 & 2014 \\
\hline \multicolumn{13}{|l|}{ Cultivar } \\
\hline Tarom Hashemi & $136.26 \mathrm{a}$ & $143.14 \mathrm{a}$ & $27.72 \mathrm{a}$ & 28.97 a & $19.20 \mathrm{a}$ & $14.54 \mathrm{a}$ & $13.33 \mathrm{a}$ & $10.26 \mathrm{a}$ & $4708.5 \mathrm{a}$ & $4444.8 \mathrm{a}$ & $43.76 \mathrm{a}$ & $43.22 \mathrm{a}$ \\
\hline Tarom Mahalli & $127.45 \mathrm{~b}$ & $130.08 \mathrm{~b}$ & $24.81 \mathrm{~b}$ & $23.68 \mathrm{a}$ & $18.19 \mathrm{~b}$ & $13.48 \mathrm{~b}$ & $12.30 \mathrm{~b}$ & $9.59 \mathrm{~b}$ & $4361.9 \mathrm{~b}$ & $4136.3 \mathrm{~b}$ & $44.55 \mathrm{a}$ & $42.88 \mathrm{a}$ \\
\hline LSD 0.05 & 7.94 & 7.24 & 0.59 & 2.05 & 1.92 & 1.41 & 2.79 & 0.73 & 677.6 & 449.63 & 7.48 & 6.70 \\
\hline \multicolumn{13}{|l|}{ Nitrogen } \\
\hline Nitroxin & $129.62 \mathrm{~b}$ & $133.93 \mathrm{a}$ & $26.51 \mathrm{a}$ & 26.47 a & $16.94 \mathrm{c}$ & $13.06 \mathrm{~b}$ & $11.56 \mathrm{~b}$ & $8.89 \mathrm{~b}$ & $4543.9 \mathrm{a}$ & $4251.1 \mathrm{a}$ & $45.07 \mathrm{a}$ & $42.02 \mathrm{~b}$ \\
\hline N34 & $133.87 \mathrm{a}$ & $138.18 \mathrm{a}$ & $26.92 \mathrm{a}$ & $26.08 \mathrm{a}$ & $18.11 \mathrm{~b}$ & $1412 \mathrm{ab}$ & $12.22 \mathrm{~b}$ & $10.22 \mathrm{a}$ & $4545.6 \mathrm{a}$ & $4276.1 \mathrm{a}$ & 44.99 a & $43.74 \mathrm{a}$ \\
\hline N69 & $132.09 \mathrm{ab}$ & $137.73 \mathrm{a}$ & $26.86 \mathrm{a}$ & $26.44 \mathrm{a}$ & $21.04 \mathrm{a}$ & $14.86 \mathrm{a}$ & $14.67 \mathrm{a}$ & $10.67 \mathrm{a}$ & $4516.1 \mathrm{a}$ & $4344.4 \mathrm{a}$ & $42.41 \mathrm{~b}$ & $43.39 \mathrm{ab}$ \\
\hline LSD 0.05 & 3.22 & 4.46 & 0.87 & 0.86 & 1.10 & 1.24 & 0.99 & 0.98 & 288.39 & 271.40 & 1.40 & 1.57 \\
\hline \multicolumn{13}{|l|}{ Nano particle } \\
\hline Control & $130.88 \mathrm{a}$ & $136.54 \mathrm{a}$ & $26.44 \mathrm{a}$ & $25.98 \mathrm{~b}$ & $18.45 \mathrm{a}$ & $13.62 \mathrm{a}$ & $12.61 \mathrm{a}$ & $9.67 \mathrm{a}$ & $4389.4 \mathrm{~b}$ & $4156.1 \mathrm{a}$ & $43.58 \mathrm{a}$ & $42.34 \mathrm{a}$ \\
\hline Nano potassium & $132.31 \mathrm{a}$ & $135.72 \mathrm{a}$ & $26.99 \mathrm{a}$ & $26.12 \mathrm{ab}$ & $18.66 \mathrm{a}$ & $14.37 \mathrm{a}$ & $12.89 \mathrm{a}$ & $10.00 \mathrm{a}$ & $4681.1 \mathrm{a}$ & $4382.2 \mathrm{a}$ & $44.64 \mathrm{a}$ & $43.35 \mathrm{a}$ \\
\hline Nano silicon & $132.39 \mathrm{a}$ & $137.57 \mathrm{a}$ & $26.86 \mathrm{a}$ & $26.88 \mathrm{a}$ & $18.98 \mathrm{a}$ & $14.62 \mathrm{a}$ & $12.94 \mathrm{a}$ & $10.11 \mathrm{a}$ & $4535.0 \mathrm{ab}$ & $4333.3 \mathrm{a}$ & $44.25 \mathrm{a}$ & $43.46 \mathrm{a}$ \\
\hline LSD 0.05 & 3.22 & 4.46 & 0.87 & 0.86 & 1.10 & 1.24 & 0.99 & 0.98 & 288.39 & 271.43 & 1.40 & 1.57 \\
\hline
\end{tabular}

Values within each column followed by same letter are not significantly different at LSD $(\mathrm{P} \leq 0.05)$. 


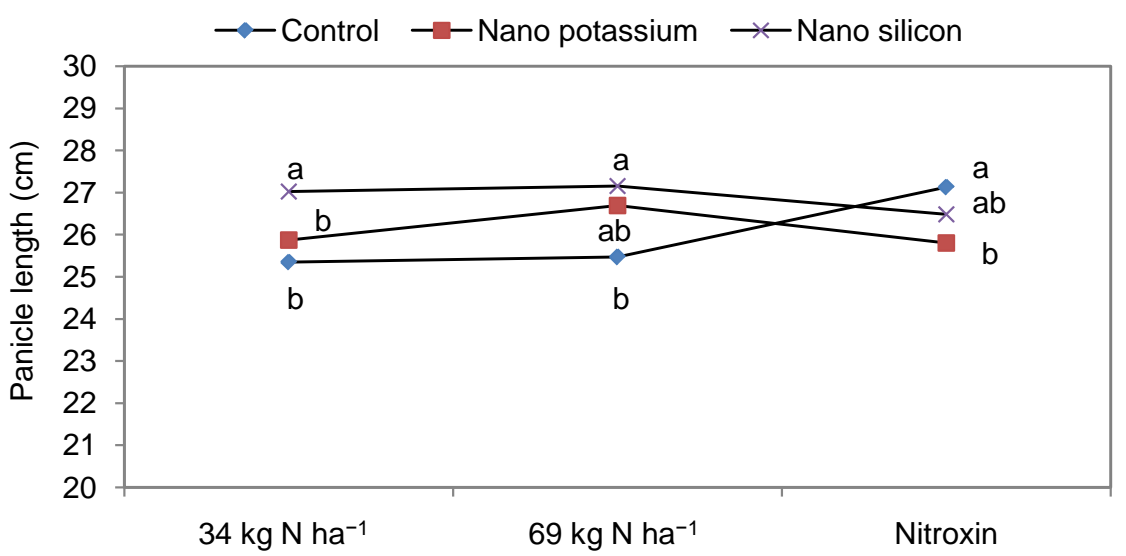

Figure 1. Interaction of nitrogen and nano particle on panicle length.

the effect of nitrogen on height was reported. Cells growth increase under nitrogen might be a reason for plant height rise [27]. Several studies indicated that exogenous application of some nanoparticles can significantly improve plant growth [28] [29]. Previous studies reported that applying $3.0 \mathrm{~L} \cdot \mathrm{ha}^{-1}$ doses of Nanonat and Ferbanat has promoted tomatoes' yield and plant growth [30]. The plant height was enhanced via using full recommended rate of nanofertilizer at 15 and 30 DAT (days after transplanting). In addition, plant height was more enhanced when nanofertilizer was mixed with the conventional ones, even at a lower application rate [31]. It has been revealed that exogenous application of nano-silicon on plants enhances the plant growth and development by increasing the accumulation of proline, free amino acids, nutrients content, antioxidant enzymes activity, gas exchange and improving photosynthetic apparatus efficiency [32] [33].

\subsection{Tiller Number and Fertile Tiller Number per Hill}

Tiller per hill and the number of fertile tiller per hill had significant effect under cultivar treatment at probability level $5 \%$ in both years. Under the simple effect of nitrogen in the $1^{\text {st }}$ year, both traits had meaningful impact under nitrogen treatment in $1 \%$ probability level. But in the $2^{\text {nd }}$ second year, the number of tiller per hill and that of fertile tiller per hill had significant effect under nitrogen treatment at probability levels $5 \%$ and $1 \%$, Respectively (Table 3 ). In both years, the number of tiller per hill (19.20 and 14.54 tillers) and that of fertile tiller per hill (13.33 and 10.26 tillers) for Tarom Hashemi were more than those of Tarom Mahalli. The max and min number of tiller per hill and the number of fertile tiller per hill in both years were observed with $69 \mathrm{~kg} \mathrm{~N}$ per hectare and nitroxin use, respectively (Table 4). Thus this behaviour is a consequence of nitrogen participating in plant structural functions such as cell multiplication and differentiation, genetic inheritance and formation of tissues.Generally, increasing trends of tiller number was seen as $\mathrm{N}$ rates increased. Similar work also confirmed increasing nitrogen rate as the number of tillers got more [34] [35] [36] [37]. Lampayan et al. (2010) suggested that tiller number rise resulted from ap- 
plying nitrogen fertilizer [38]. The number of effective tillers produced is a good indicator as it is a major yield determinant. Tiller number increased by $\mathrm{N}$ levels increase [39]. Applying $150 \mathrm{~kg} \mathrm{~N} \mathrm{ha}^{-1}$ and nitrogen of $33.3 \%-50 \%$ at the onset of tilleringled to the number of tiller per hill increase [40]. The number of reproductive tillers was significantly affected by applying conventional fertilizer and its combination with nano-fertilizer [31].

\subsection{Paddy Yield}

This parameter had critical impact under cultivar treatment at probability level $1 \%$ in both years. Also in the 2nd year, paddy yield was meaningful under the triple interaction of $\mathrm{C} \times \mathrm{N} \times \mathrm{P}$ at probability level $5 \%$ (Table 3 ). The paddy yield for Tarom Hashemi was more than Tarom Mahalli in both years (Table 4). Triple interaction showed that the highest paddy yield $\left(5000 \mathrm{~kg} \cdot \mathrm{ha}^{-1}\right)$ for Tarom Hashemi was produced with $34 \mathrm{~kg} \mathrm{~N} \mathrm{ha}^{-1}$ and nano potassium use. Also for this cultivar, the keast paddy yield $4133 \mathrm{~kg} \cdot \mathrm{ha}^{-1}$ was observed with $69 \mathrm{~kg} \mathrm{~N} \mathrm{ha}^{-1}$ and control treatment. For Tarom Mahalli, the max paddy yield $\left(4657 \mathrm{~kg} \cdot \mathrm{ha}^{-1}\right)$ was obtained with applying nitroxin and nano potassium. Also the keast of that 3667 $\mathrm{kg} \mathrm{N} \mathrm{ha}^{-1}$ was spotted with nitroxin use and control treatment (Table 5). Nitrogen is an essential nutrient for rice production and plays an important role in

Table 5. Mean comparison of interaction of cultivar and nitrogen and nano fertilizer in paddy yield in 2014 .

\begin{tabular}{|c|c|c|c|}
\hline \multicolumn{3}{|c|}{ Treatment } & \multirow{2}{*}{ Paddy yield $\left(\mathrm{k} \cdot \mathrm{ha}^{-1}\right)$} \\
\hline Cultivar & Nitrogen & Nano particle & \\
\hline & & Control & $4533 \mathrm{bc}$ \\
\hline & Nitroxin & Nano potassium & $4200 \mathrm{~cd}$ \\
\hline & & Nano silicon & $4400 \mathrm{bcd}$ \\
\hline & & Control & $4267 \mathrm{~cd}$ \\
\hline \multirow[t]{9}{*}{ Tarom Hashemi } & N34 & Nano potassium & $5000 \mathrm{a}$ \\
\hline & & Nano silicon & $4500 \mathrm{bc}$ \\
\hline & & Control & $4133 d$ \\
\hline & N69 & Nano potassium & $4337 \mathrm{~cd}$ \\
\hline & & Nano silicon & $4633 \mathrm{~b}$ \\
\hline & & Control & $3667 c$ \\
\hline & Nitroxin & Nano potassium & 4657 a \\
\hline & & Nano silicon & $4200 \mathrm{ab}$ \\
\hline & & Control & $4033 \mathrm{~b}$ \\
\hline \multirow[t]{5}{*}{ Tarom Mahalli } & N34 & Nano potassium & $4200 \mathrm{ab}$ \\
\hline & & Nano silicon & $4067 \mathrm{~b}$ \\
\hline & & Control & $4303 \mathrm{ab}$ \\
\hline & N69 & Nano potassium & $3900 \mathrm{bc}$ \\
\hline & & Nano silicon & $4200 \mathrm{ab}$ \\
\hline
\end{tabular}

Values within each column followed by same letter are not significantly different at LSD $(\mathrm{P} \leq 0.05)$. 
sustaining high yields [41]. Soil nitrogen supply shortage is one of the main limiting factors for achieving high rice yields, and nitrogen fertilizer is an important component in rice production [42]. Nitrogen application level increase could critically raise rice production within limits [43] [44]. Nitrogen as one of the main nutrients in agricultural production, might be given only very few parts to plant and soil need, though reports stated that using very small nanofertilizer particles is more effective than this rate [45]. The researchers suggested that nano-fertilizers considerably influenced the straw yield and grain yield [46] [47] [48] [49] [50]. Several studies proved the significance of nanofertilizers. For instance, Sirisena et al. (2013) gained higher grain yield in rice via applying nano-K fertilizer [7]. This is in agreement with the findings of Liu and et al. (2009) reporting that nanofertilizer application increased crop yield by $20 \%-40 \%$ [51]. Another experiment conducted by Delfani et al. (2014) obtained the highest yield in black-eyed pea ( $245 \mathrm{~g}$, a $13.5 \%$ increase over the control) when a regular Fe salt fertilizer was combined with Mg-NPs [52].

\subsection{Harvest Index}

Harvest index had significant effect under nitrogen treatment at probability levels $1 \%$ and $5 \%$ in the 1 st year and 2 nd year, respectively. Also in the $1^{\text {st }}$ year, Harvest index was significant under the double interaction of nitrogen and nano particle at probability level $5 \%$ (Table 3 ). In the first year, the lowest harvest index was observed with $69 \mathrm{~kg} \mathrm{~N}$ per hectare as $42.41 \%$. In the second year, the maximum harvest index as $43.74 \%$ was gained by $34 \mathrm{~kg} \mathrm{~N}$ hectare and the minimum harvest index $42.02 \%$ was obtained by nitroxin use (Table 4 ). At the interaction of nitrogen and nano fertilizer, the highest harvest index $46.59 \%$ was achieved with nitroxin and nano silicon use. Also the lowest harvest index $41.78 \%$ was gained by $69 \mathrm{~kg} \mathrm{~N}$ per hectare and nano silicon use (Figure 2). The physiological efficiency and ability of a crop to convert the total dry matter into economic yield is known as harvest index (HI). Nitrogen rates showed significant difference for HI. Means comparison indicated the maximum harvest index was recorded when $225 \mathrm{~kg} \mathrm{~N} \mathrm{ha}^{-1}$ was applied [53]. Harvest index increase

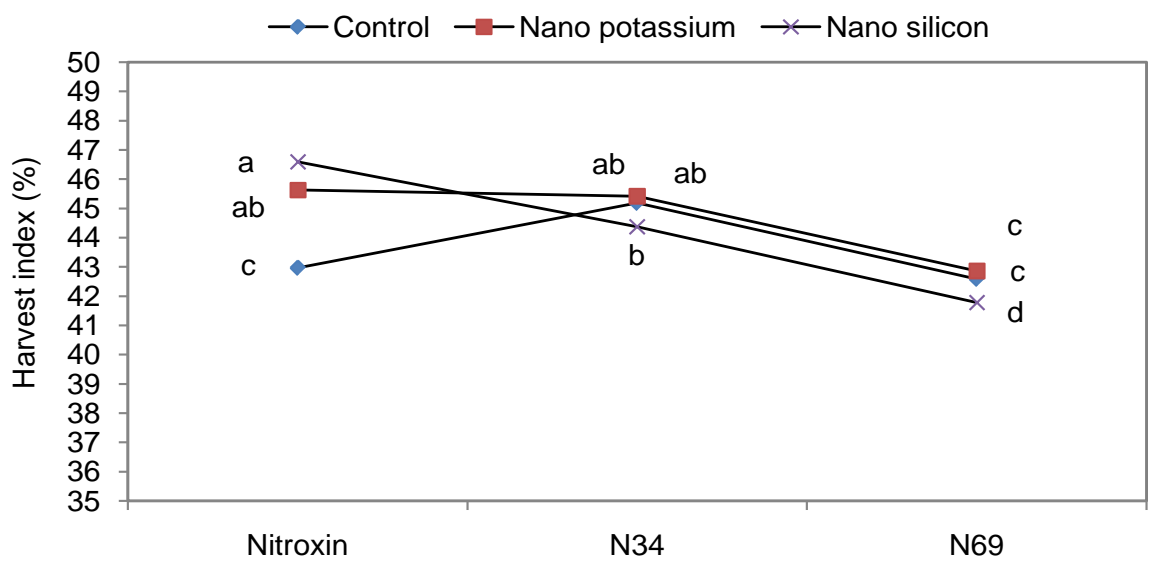

Figure 2. Interaction of nitrogen and nano fertilizer on harvest index. 
would mean improvement in grain yield. It seems that the function of nanofertilizer at the reproductive stage of rice was only supplemental. Nonetheless, it was evident that nanofertilizer application enhanced the abovementioned parameters. Nanofertilizer may have synergistic effect on the conventional fertilizer for better nutrient absorption by plant cells resulting in optimal growth [31]. Janmohammadi et al. (2016) denoted that a significant increase of grain yield in response to nanofertilizer use statistically improved the harvest index (HI) compared with control [46].

\section{Conclusions}

Plant nutrients, primarily originating from chemical fertilizer, are essential for crop production. Nitrogen is an essential element for crop growth and development in agriculture; it is the basic constituent of chlorophyll, proteins and all enzymes involved in photosynthesis, especially Rubisco which alone accounts for more than $75 \%$ of the total leaf nitrogen. Rice plants require large amounts of mineral nutrients including nitrogen for their growth, development, and grain production. Rice grain yield increased by nitrogen fertilizer use rate rise. At the same time, nitrogen has been known as an important factor influencing rice milling quality.

A lot of studies noted that the nitrogen use efficiency is relatively low in paddy fields. This indicates that a major portion of applied nitrogen is wasted in paddy fields. Nitrogen losses occur through denitrification, volatilization, and leaching which may cause air and water pollutions. Therefore, reducing the chemical nitrogen rate by applying the bio fertilizers may be a solution. Bio-fertilizers are substances comprising living microorganisms that stimulate the plant growth by increasing the primary nutrients supply or availability for the plant and growth promoting substances synthesis.

On the other hand, in the last few years, some researchers tried to examine the potential of nanotechnology to improve fertilizer use efficiency. These efforts led to nano-fertilizer design and development. Nano formulated fertilizers can be easily absorbed by plants and they may exhibit prolonged effective nutrient supply duration in soil or on plant. Nanotechnology-based fertilizers could be more soluble or more reactive than their bulk counterparts. Applying nano-fertilizers may improve soil insoluble nutrients' solubility and dispersion, reduce nutrient immobilization (soil fixation) and increase bio-availability.

This study derived results exhibit two important subjects. Firstly, modified cultivars have higher fertility than older cultivars. Secondly, nano-potassium more contributes to increased performance compared to nano-silica. So that, in the presence of nano potassium, the highest grain yield for Tarom Hashemi and Tarom Mahalli cultivar was obtained with $34 \mathrm{~kg} \mathrm{~N} / \mathrm{ha}$ and nitroxin, respectively.

\section{References}

[1] FAO (Food and Agriculture Organization of the United Nations) (2011) FAOSTAT 
Statistical Database.

[2] He, Y.Q. (2005) Influence of Plants Synergist “Qiangdi Nanometer 863” on Seedling Quality and Yield of Rice. Guangxi Agricultural Science, 4, 294-295.

[3] Liu, A.X., Lu, Q.M., Cao, Y.J., Liao, Z.W. and Xu, Q.H. (2007) Effects of Composite Nanomaterials on Rice Growth. Plant Nutrition and Fertilizer Science, 2, 344-347.

[4] Zhang, S.S., Zhang, J.S., Yan, J.Z., Liu, S.S., Peng, C.A., Dong, Y.Z., Liu, G.X. and Wu, D.M. (2007) Application Effect in Early Rice Production of Farm Oriented Active Source of Water. Hubei Agricultural Sciences, 2, 204-205.

[5] Wang, X.Y., Wang, Y., Tian, X.H. and Ma, G.H. (2011) Effects of NM Urea on Nitrogen Run of Losses of Surface Water and Nitrogen Fertilizer Efficiency in Paddy Field. Transactions of the Chinese Society of Agricultural Engineering, 1, 106-111.

[6] Gong, C.L. and Dong, G.Z. (2012) First Exploration of Effects of "Nanometer 863" Biological Promote Growth Device Application in Rice Production. Rice, 5, 68-69.

[7] Sirisena, D.N., Dissanayake, D.M.N., Somaweera, K.A.T.N., Karunaratne, V. and Kottegoda, N. (2013) Use of Nano-K Fertilizer as a Source of Potassium in Rice Cultivation. Annals of Sri Lanka Department of Agriculture, 15, 257-262.

[8] Huang, S., Wang, L., Liu, L., Hou, Y. and Li, L. (2014) Nanotechnology in Agriculture, Livestock, and Aquaculture in China. A Review. Agronomy for Sustainable Development, 35, 369-400. https://doi.org/10.1007/s13593-014-0274-x

[9] Liu, R. and Lal, R. (2015) Potentials of Engineered Nanoparticles as Fertilizers for Increasing Agronomic Productions. A Review. Science of the Total Environment, 514, 131-139. https://doi.org/10.1016/j.scitotenv.2015.01.104

[10] Naderi, M.R. and Danesh-Sharaki, A.(2013) Nanofertilizers and Their Role in Sustainable Agriculture. International Journal of Agriculture and Crop Sciences, 5, 2229-2232.

[11] Masum, S.M., Ali, M.H., Mandal, M.S.H., Chowdhury, I.F. and Parveen, K. (2013) The Effect of Nitrogen and Zinc Application on Yield and Some Agronomic Characters of Rice cv. BRRI dhan33. International Research Journal of Applied and Basic Sciences, 4, 2256-2263.

[12] Ma, J.F. (2004) Role of Silicon in Enhancing the Resistance of Plants to Biotic and Abiotic Stresses. Soil Science and Plant Nutrition, 50, 11-18. https://doi.org/10.1080/00380768.2004.10408447

[13] Senanayake, N., Naylor, R.E.L., De-Datta, S.K. and Thomson, W.J. (1994) Variation in Development of Contrasting Rice Cultivars. Journal of Agricultural Science, 123, 35-39. https://doi.org/10.1017/S0021859600067745

[14] Singh, U., Ladha, J.K., Castillo, E.G., Punzalan, G., Tirol-Padre, A. and Duqueza, M. (1998) Genotypic Variation in Nitrogen Use Efficiency in Medium and Long-Duration Rice. Field Crops Research, 58, 35-53. https://doi.org/10.1016/S0378-4290(98)00084-7

[15] Mosse, J. (1990) Nitrogen to Protein Conversion Factor for Ten Cereals and Six Legumes or Oilseeds. A Reappraisal of Its Definition and Determination. Variation According to Species and to Seed Protein Content. Journal of Agricultural and Food Chemistry, 38, 18-24. https://doi.org/10.1021/jf00091a004

[16] Obanni, M., Mitchell, C. and Medcalf, D. (1998) Healthy Ingredients and Foods from Rice. Cereal Foods World, 43, 696-698.

[17] Deren, C.W., Datnoff, L.E., Snyder, G.H. and Martin, F.G. (1994) Silicon Concentration, Disease Response, and Yield Components of Rice Genotypes Grown on Flooded Organic Histosols. Crop Science, 34, 733-737. 
https://doi.org/10.1021/jf00091a004

[18] Savant, N.K., Datnoff, L.E. and Snyder, G.H. (1997) Depletion of Plant-Available Silicon in Soils: A Possible Cause of Declining Rice Yields. Communications in Soil Science and Plant Analysis, 28, 1245-1252. https://doi.org/10.1080/00103629709369870

[19] Mauad, M., Crusciol, C.A.C., Grassi-Filho, H. and Correa, J.C. (2003) Nitrogen and Silicon Fertilization of Upland Rice. Scientia Agricola, 60, 761-765. https://doi.org/10.1590/S0103-90162003000400023

[20] Yoshida, S., Ohnishi, Y. and Kitagishi, K. (1962) Chemical Forms, Mobility and Deposition of Silicon in Rice Plant. Soil Science and Plant Nutrition, 8, 15-21. https://doi.org/10.1080/00380768.1962.10430992

[21] Yoshida, S., Naveser, S.A. and Ramirez, E.A. (1969) Effects of Silica and Nitrogen Supply on Some Leaf Characters of Rice Plant. Plant and Soil, 31, 48-56. https://doi.org/10.1007/BF01373025

[22] Dastan, S., Taheri, A., Rezaei-Taleshi, S.A.A. and Siavoshi, M. (2013) Effect of Water Stress and Silicon Amount on Yield and Yield Contributing in Rice (Oryza sativa L.). Annals of Biological Research, 4, 205-208.

[23] Datnoff, L.E., Deren, C.W. and Snyder, G.H. (1997) Silicon Fertilization for Disease Management of Rice in Florida. Crop Protection, 16, 525-531. https://doi.org/10.1016/S0261-2194(97)00033-1

[24] Ma, J.F., Miyake, Y. and Takahashi, E. (2002) Silicon as a Beneficial Element for Crop Plants. Studies in Plant Science, 8, 17-39. https://doi.org/10.1016/S0928-3420(01)80006-9

[25] Seebold, K., Datnoff, L.E., Correa, V.F. and Snyder, G.H. (1995) Effects of Silicon and Fungicides on Leaf and Neck Blast Development in Rice. Phytopathology, 85, 1168.

[26] Jalali-Moridani, M. and Amiri, E. (2014) Effect of Nitrogen and Potassium on Yield and Yield Components of Rice Cultivar "Hashemi". Indian Journal of Fundamental and Applied Life Sciences, 4, 417-424.

[27] Bahmaniar, M.A. and Sooaee-Mashaee, S. (2010) Infiuence of Nitrogen and Potassium Top Dressing on Yield and Yield Components as Well as Well as Their Accumulation in Rice Oryzasativa. African Journal of Biology, 9, 2648-2653.

[28] Mandeh, M., Omidi, M. and Rahaie, M. (2012) In Vitro Influences of $\mathrm{TiO}_{2} \mathrm{Nano}^{-}$ particles on Barley (Hordeum vulgare L.) Tissue Culture. Biological Trace Element Research, 150, 376-380. https://doi.org/10.1007/s12011-012-9480-z

[29] Song, U., Shin, M., Lee, G., Roh, J., Kim, Y. and Lee, E.J. (2013) Functional Analysis of $\mathrm{TiO}_{2}$ Nanoparticle Toxicity in Three Plant Species. Biological Trace Element Research, 155, 93-103. https://doi.org/10.1007/s12011-013-9765-x

[30] Ekinci, M., Dursun, A., Yildirim, E. and Parlakova, F. (2012) The Effects of Nanotechnological Liquid Fertilizers on Plant Growth and Yield in Tomato. 9. UlusalSebze Tarimi Sempozyumu, Konya, 14-12 Eylül 2012, 326-329. (In Turkish)

[31] Benzon, H.R.L., Rubenecia, M.R.U., Jr, V.U.U. and Lee, S.C. (2015) Nano-Fertilizer Affects the Growth, Development, and Chemical Properties of Rice. International Journal of Agronomy and Agricultural Research (IJAAR), 7, 105-117.

[32] Xie, Y., Li, B., Zhang, Q. and Zhang, C. (2012). Effects of Nano-Silicon Dioxide on Photosynthetic Fluorescence Characteristics of Indocalamus barbatus McClure. Journal of Nanjing Forestry University (Natural Science Edition), 2, 59-63.

[33] Kalteh, M., Alipour, Z.T., Ashraf, S., Aliabadi, M.M. and Nosratabadi, A.F. (2014) 
Effect of Silica Nanoparticles on Basil (Ocimum basilicum) under Salinity Stress. Journal of Chemical Health Risks, 4, 49-55.

[34] Abdo, W., Geremew, B. and Asefa, T. (2012) Effect of Different Nitrogen Fertilizer Rates on Yield and Yield Related Traits for Seven Durum Wheat (Triticum turgidum L. var Durum) Cultivars Grown at Sinana South Eastern Ethiopia. AJFAND, 12, 6079-6094.

[35] Girma, F., Haile, D., Reta, D., Mengistu, B., Seyfudin, M. and Firehiwot, G. (2012) Grain Hardness, Hectolitre Weight, Nitrogen and Phosphorus Concentrations of Durum Wheat (Triticum turgidum L. var. Durum) as Influenced by Nitrogen and Phosphorus Fertilisation. World Applied Sciences Journal, 20, 1322-1327.

[36] Haile, D., Nigusse, D. and Amsalu, A. (2012) Nitrogen Use Efficiency of Bread Wheat: Effects of Nitrogen Rate and Time of Application. Journal of Soil Science and Plant Nutrition, 12, 389-410.

[37] Gerba, L., Getachew, B. and Walelign, W. (2013) Nitrogen Fertilization Effects on Grain Quality of Durum Wheat (Triticum turgidum L. var. Durum) Varieties in Central Ethiopia Agricultural Sciences. Agricultural Sciences, 4, 123-130. https://doi.org/10.4236/as.2013.43019

[38] Lampayan, R.M., Bouman, B.A.M., Dios, J.L.D., Espiritu, A.J., Soriano, J.B. and Lactaoen, A.T. (2010) Yield of Aerobic Rice in Rain Fed Lowlands of the Philippines as Affected by Nitrogen Management and Row Spacing. Field Crops Research, 116, 165-174. https://doi.org/10.1016/j.fcr.2009.12.007

[39] Mohammed Moro, B., Roland Nuhu, I., Ato, E. and Nathanial, B. (2015) Effect of Nitrogen Rates on the Growth and Yield of Three Rice (Oryza sativa L.) Varieties in Rain-Fed Lowland in the Forest Agro-Ecological Zone of Ghana. International Journal of Agricultural Sciences, 5, 878-885.

[40] Mobasser, H.R., Ghanbari-Malidareh, A. and Sedghi, A.H. (2008) Effect of Silicon Application to Nitrogen Rate and 435 Plitting on Agronomical Characteristics of Rice (Oryza sativa L.). Silicon in Agriculture Conference, Wild Coast Sun, South Africa, 26-31 October 2008.

[41] Yang, S.N., Yu, Q.G., Ye, J., Jiang, N., Ma, J.W., Wang, Q., Wang, J.M., Sun, W.C. and Fu, J.R. (2010) Effects of Nitrogen Fertilization on Yield and Nitrogen Use Efficiency of Hybrid Rice. Acta Metallurgica Sinica, 16, 1120-1125. (In Chinese with English Abstract)

[42] Duan, Y.H., Zhang, Y.L., Shen, Q.R., Chen, H.Y., Zhang, Y. (2005) Effect of Partial Replacement of $\mathrm{NH}_{4}{ }^{+}$by $\mathrm{NO}_{3}{ }^{-}$on Nitrogen Uptake and Utilization by Different Genotypes of Rice at the Seedling Stage. Acta Metallurgica Sinica, 11, 160-165. (In Chinese with English Abstract)

[43] Wang, W.N., Lu, J.W., He, Y.Q., Li, X.K. and Li, H. (2011) Effects of N, P, K Fertilizer Application on Grain Yield, Quality, Nutrient Uptake and Utilization of Rice. Chinese Journal of Rice Science, 25, 645-653. (In Chinese with English Abstract)

[44] Wu, C.Y., Tang, X., Chen, Y., Yang, S.M. and Ye, S.H. (2011) Effect of Fertilization Systems on Yield and Nutrients Absorption in Japonica Rice Variety Zhejing 22. ActaAgric Zhejiang, 23, 132-137. (In Chinese with English Abstract)

[45] DeRosa, M.C., Monreal, C., Schnitzer, M., Walsh, R. and Sultan, Y. (2010) Nanotechnology in Fertilizers. Nature Nanotechnology, 5, 91.

https://doi.org/10.1038/nnano.2010.2

[46] Janmohammadi, M., Amanzadeh, T., Sabaghnia, N. and Dashti, S. (2016) Impact of Foliar Application of Nano Micronutrient Fertilizers and Titanium Dioxide Nanoparticles on the Growth and Yield Components of Barley under Supplemental Irri- 
gation. Actaagriculturae Slovenica, 107, 265-276.

https://doi.org/10.14720/aas.2016.107.2.01

[47] Gao, J., Xu, G., Qian, H., Liu, P., Zhao, P. and Hu, Y. (2013) Effects of Nano-TiO 2 on Photosynthetic Characteristics of Ulmuselongata Seedlings. Environmental Pollution, 176, 63-70. https://doi.org/10.1016/j.envpol.2013.01.027

[48] Morteza, E., Moaveni, P., Farahani, H.A. and Kiyani, M. (2013) Study of Photosynthetic Pigments Changes of Maize (Zea mays L.) under Nano $\mathrm{TiO}_{2}$ Spraying at Various Growth Stages. SpringerPlus, 2, 1-5. https://doi.org/10.1186/2193-1801-2-247

[49] Klingenfuss, F. (2014) Testing of $\mathrm{TiO}_{2}$ Nanoparticles on Wheat and Microorganisms in a Soil Microcosm. Thesis for Master of Science in Ecotoxicology, University of Gothenburg, Gothenburg, 62.

[50] Tarafdar, J.C., Raliya, R., Mahawar, H. and Rathore, I. (2014) Development of Zinc Nanofertilizer to Enhance Crop Production in Pearl Millet (Pennisetum americanum). Agricultural Research, 3, 257-262. https://doi.org/10.1007/s40003-014-0113-y

[51] Liu, J., Zhang, Y. and Zhang, Z. (2009) The Application Research on Nano-Biotechnology to Promote Increasing Vegetable Production. Hubei Agricultural Sciences, 1, 20-25.

[52] Delfani, M., Firouzabadi, M.B., Farrokhi, N. and Makarian, H. (2014) Some Physiological Responses of Black-Eyed Pea to Iron and Magnesium Nanofertilizers. Communications in Soil Science and Plant Analysis, 45, 530-540. https://doi.org/10.1080/00103624.2013.863911

[53] Nemati, A.R. and Seyed Sharifi, R. (2012) Effects of Rates and Nitrogen Application Timing on Yield, Agronomic Characterstics and Nitrogen Use Efficiency in Corn. International Journal of Agriculture and Crop Sciences, 4, 534-539.

Scientific Research Publishing

\section{Submit or recommend next manuscript to SCIRP and we will provide best} service for you:

Accepting pre-submission inquiries through Email, Facebook, LinkedIn, Twitter, etc. A wide selection of journals (inclusive of 9 subjects, more than 200 journals)

Providing 24-hour high-quality service

User-friendly online submission system

Fair and swift peer-review system

Efficient typesetting and proofreading procedure

Display of the result of downloads and visits, as well as the number of cited articles

Maximum dissemination of your research work

Submit your manuscript at: http://papersubmission.scirp.org/

Or contact oje@scirp.org 